\title{
NOTES ON CONTRIBUTORS
}

DANA ARNOLD is Professor of Architectural History at the University of Southampton and Director of the Centre for Studies in Architecture and Urbanism. Her recent publications include: A Very Short Introduction to Art History, Oxford University Press, 2003; Reading Architectural History, Routledge, 2002; Re-presenting the Metropolis: Architecture, Urban Experience and Social Life in London, Ashgate, 2000; and the edited volumes (with Margaret Iversen) Art and Thought, Blackwell, 2003, and The Metropolis and its Image: Constructing Identities for London c.1750-1950, Blackwell, 1999. She is the series editor of New Interventions in Art History and general editor of two further series: Companions to Art History and Anthologies in Art History, all published by Blackwell. An anthology of her writings on London will be published by Manchester University Press in 2004.

ANDREW BALLANTYNE is Professor of Architecture at the University of Newcastle upon Tyne and Director of the Centre for Tectonic Cultures. His books include: Architecture, Landscape and Liberty: Richard Payne Knight and the Picturesque, Cambridge University Press, 1997; What Is Architecture? Routledge, 2001, and Architecture: A Very Short Introduction, Oxford University Press, 2002. He is the editor of: Architectures: Modernism and After, in the Blackwell series New Interventions in Art History; Architecture Theory, Continuum; and (with Dana Arnold) Architecture as Experience, published by Routledge.

FREDERICK N. BOHRER is Associate Professor of Art at Hood College in Frederick, Maryland (USA). He is the author of Orientalism and Visual Culture: Imagining Mesopotamia in 19th Century Europe, Cambridge University Press, 2003, and the editor of Antoin Sevruguin and the Persian Image: Photographs from Iran 1870-1930, Smithsonian Institution and University of Washington Press, 1999.

JULIE F. CODELL is Professor of Art History at Arizona State University. She has received six National Endowment for the Humanities' fellowships and grants and a fellowship from the Yale British Art Center. Her articles on Victorian art and culture have appeared in many scholarly journals, anthologies of collected essays and encyclopaedias. She wrote Lives of the Artists: Artists' Lifewritings in Britain, c.1870-1910, Cambridge University Press, 2002, and co-edited Orientalism Transposed: The Impact of the Colonies on British Culture, Ashgate, 1998. She is currently preparing a book entitled 'Nothing but the Sight': Visuality, Culture, and Imperial Identities in the Delhi Coronation Durbars and their Exhibitions of Indian Art, 1877-1910, to be published in 2003. 


\section{CONTRIBUTORS}

MARK CRINSON is Senior Lecturer at the University of Manchester, where he is also Head of the School of Art History and Archaeology. His books include: Architecture - Art or Profession? 300 Years of Architectural Education (with Jules Lubbock), Manchester University Press, 1994; Empire Building: Orientalism and Victorian Architecture, Routledge, 1996; and Modern Architecture and the End of Empire, Ashgate, 2002.

SOPHIA CROSS was born in Northern Ireland. She holds an MA in Country House Studies from Leeds University and is currently undertaking a part-time $\mathrm{PhD}$ at Southampton University entitled 'The Irish Country House 17901840: an exploration of identities and meanings'.

FINTAN CULLEN is Head of the Department of Art History and the author of Visual Politics. The Representation of Ireland 1750-1930, 1997, and Sources in Irish Art: A Reader, 2000, both published by Cork University Press. His contribution to this volume forms part of a forthcoming study on the politics of display in colonial Ireland. He has recently completed a book on Irish portraiture for the National Portrait Gallery, London.

JOCELYN HACKFORTH-JONES is Professor of Art History and Provost at Richmond, the American International University, London. She has published extensively on landscape painting and colonialism, as well as intercultural education and the visual arts. Her most recent book is (Re)Forming Identities: Intercultural Education and the Visual Arts. She is currently working on an exhibition for the National Portrait Gallery, London, titled 'London's Complexions. The Visual Representation of Non-Europeans in London, c. 1750-1850' scheduled for 2006.

CYNTHIA E. ROMAN assumed the position of Curator of Prints, Drawings, and Paintings at the Lewis Walpole Library, Yale University in May 2003. Prior to that she was Associate Curator of European Art at the Wadsworth Atheneum Museum of Art, Hartford, Connecticut and Acting Director of the Watson Art Gallery, Wheaton College. Dr. Roman received her PhD from Brown University in 1997 writing her dissertation on Robert Bowyer's Historic Galley. She has taught courses in the history of art at Saint Joseph College, the University of Hartford, and Trinity College, Hartford. She was curator and catalogue author for the exhibition From Canaletto to Constable: Paintings of Town and Country from the Yale Center for British Art for venues in Hartford (1998) and Ferrara, Italy (2001) and has organized many exhibitions from the permanent collection of prints and drawings at the Wadsworth Atheneum.

SAM SMILES lectures in art history at Plymouth University. He has written widely on British art c.1750-1940. His books include The Image of Antiquity: Ancient Britain and the Romantic Imagination, Yale University Press, 1994, as well as studies on Turner and aspects of pictorial representation in the eighteenth and nineteenth centuries. 
Dana Arnold - 9781526117519

Downloaded from manchesterhive.com at 04/26/2023 09:33:22AM via free access 